\title{
DOWNREGULATION OF ADIPOR1 IS ASSOCIATED WITH INCREASED CIRCULATING ADIPONECTIN LEVELS IN SERBIAN CHRONIC KIDNEY DISEASE PATIENTS
}

\author{
NISHODNA REGULACIJA ADIPOR1 JE UDRUŽENA SA POVIŠENOM KONCENTRACIJOM CIRKULIŠUĆEG \\ ADIPONEKTINA KOD SRPSKIH PACIJENATA SA HRONIČNOM BUBREŽNOM INSUFICIJENCIJOM
}

\author{
Miron Sopić1, Jelena Joksić1, Vesna Spasojević-Kalimanovska1, Nataša Bogavac-Stanojević1, \\ Sanja Simić-Ogrizović ${ }^{2,3}$, Milica Kravljača ${ }^{2}$, Zorana Jelić Ivanović1 \\ ${ }^{1}$ Department of Medical Biochemistry, Faculty of Pharmacy, University of Belgrade, Belgrade, Serbia \\ ${ }^{2}$ Clinic of Nephrology, Clinical Center of Serbia, Belgrade, Serbia \\ ${ }^{3}$ School of Medicine, University of Belgrade, Serbia
}

\begin{abstract}
Summary
Background: Since the rise in plasma adiponectin levels in chronic kidney disease (CKD) patients has not yet been elucidated, we sought to investigate if patients on hemodialysis (HD) have altered expression of adiponectin receptors in peripheral blood mononuclear cells (PBMCs) compared to healthy subjects.

Methods: This study included 31 patients with chronic kidney disease on HD and 33 healthy subjects (CG). Circulating adiponectin levels were measured by ELISA while AdipoR1 and AdipoR2 mRNA levels in PBMCs were determined by real-time PCR.

Results: Plasma adiponectin levels were significantly higher in patients compared to control group $(P=0.036)$. After adjustment for age, BMI and creatinine, this difference became even more significant $(P=0.004)$. In both groups adiponectin correlated with creatinine (CG: $r=-0.472$, $P=0.006$; HD: $r=-0.375, P=0.038$ ), triglycerides (CG: $r=$ $0.490, P=0.004$; HD: $r=-0.488, P=0.005)$, insulin (CG: $r=-0.386, P=0.038$; HD: $r=-0.506, P=0.012)$ and high density lipoprotein cholesterol (HDL-C) (CG: $r=-0.672$, $P<0.001 ; H D: r=-0.584, P=0.001)$. Significantly lower expression of PBMCs AdipoR1 mRNA was found in patients compared to CG $(P=0.034)$, while AdipoR2 mRNA levels were similarly expressed in PBMCs in both groups.

Conclusions: Complex pathological processes in CKD cause downregulation of AdipoR1 which could ultimately influence AdipoR1 protein levels leading to a state of »adiponectin resistance».
\end{abstract}

Keywords: adiponectin, AdipoR1, AdipoR2, chronic kidney disease

Address for correspondence:

Miron Sopić

Faculty of Pharmacy, University of Belgrade,

Vojvode Stepe 450, 11000 Belgrade, Serbia

\section{Kratak sadržaj}

Uvod: S obzirom na to da razlozi povišenih vrednosti adiponektina u hroničnoj bubrežnoj insuficijenciji (HBI) još uvek nisu razjašnjeni, cilj ovog istraživanja bio je da se ispita da li pacijenti na hemodijalizi (HD) imaju promenjen nivo genske ekspresije adiponektinskih receptora u mononuklearnim ćelijama periferne krvi u odnosu na zdrave ispitanike.

Metode: Ova studija je obuhvatila 31 pacijenta sa hroničnom bubrežnom insuficijencijom na hemodijalizi (HD) i 33 zdrava ispitanika (KG). Koncentracija cirkulišućeg adiponektina određena je ELISA metodom, a nivoi iRNK adiponektinskih receptora AdipoR1 i AdipoR2 u mononuklearnim ćelijama periferne krvi određeni su metodom real-time $P C R$.

Rezultati: Koncentracija adiponektina u plazmi pacijenata bila je značajno viša $u$ odnosu na zdrave ispitanike ( $P=$ 0,036). Nakon korekcije za godine, BMI i koncentraciju kreatinina, ova razlika je postala još značajnija $(P=0,004)$. $U$ obe grupe ispitanika koncentracija adiponektina je korelisala sa koncentracijom kreatinina (KG: $r=-0,472$, $\mathrm{P}=0,006$; $\mathrm{HD}: \mathrm{r}=-0,375, \mathrm{P}=0,038)$, koncentracijom triglicerida (KG: $r=-0,490, P=0,004 ; H D: r=-0,488$, $\mathrm{P}=0,005)$, koncentracijom insulina (KG: $r=-0,386$, $P=0,038 ; H D: r=-0,506, P=0,012)$ i koncentracijom holesterola u lipoproteinima velike gustine (KG: $r=-0,672$, $\mathrm{P}<0,001$; HD: $r=-0,584, P=0,001)$. Pacijenti su imali značajno niži nivo iRNK AdipoR1 u mononuklearnim ćelijama periferne krvi u poređenju sa zdravim ispitanicima $(P=0,034)$, dok se nivo iRNK AdipoR2 nije značajno razlikovao među posmatranim grupama.

Zaključak: Kompleksni patološki procesi u HBI izazivaju nishodnu regulaciju AdipoR1 gena, što bi moglo uticati na nivo AdipoR1 proteina, vodeći u stanje »adiponektinske rezistencije«.

Ključne reči: adiponektin, AdipoR1, AdipoR2, hronična bubrežna insuficijencija 


\section{Introduction}

Adiponectin is a protein abundantly secreted by adipose tissue (1). It is generally considered a molecule with antiinflammatory, atheroprotective and antiapoptotic effects which are mainly achieved via activation of two ubiquitously expressed adiponectin receptors, AdipoR1 and AdipoR2 (2). Activation of AdipoR1 leads to increased sensitivity of peripheral tissues to insulin, while AdipoR2 activation increases fatty acid combustion $(1,2)$. Although the mechanism is not well understood, it has been shown that adiponectin via these two receptors also activates ceramidase which is important for its antiapoptotic effects (3).

Peripheral blood mononuclear cells (PBMC) and macrophages express both AdipoR1 and AdipoR2 allowing adiponectin to affect directly their function. Under this influence, macrophages increase IL10 secretion and shift from the proinflammatory $M 1$ to the antiinflammatory $M 2$ phenotype $(4,5)$. It has also been shown that adiponectin exerts protective effects on kidneys by decreasing podocytes albumin permeability in mice (6). It seems that adiponectin downregulates podocytes NADPH oxidase production via AdipoR1 thus decreasing oxidative stress in these cells (7). Martinez et al. suggested that increased oxidative stress together with the altered gene expression of adiponectin receptors could be related to increased insulin resistance in patients with end-stage renal kidney disease (18).

Patients with chronic kidney disease (CKD) are greatly exposed to high risk of cardiovascular disease (CVD) mortality due to the presence of several traditional and nontraditional risk factors $(8,9)$. Previous studies consistently reported that adiponectin levels are increased in patients with CKD, but the reasons for this phenomenon have remained unclear. Possible explanations include metabolic changes in uremia, reduced adiponectin clearance by kidneys and changes in ligand/receptor reactivity (10-12). Although it was suggested that kidneys play an important role in adiponectin clearance, it has been shown that in successful renal transplantation adiponectin levels do decrease, but still remain higher compared to healthy individuals (13). On the other hand, Halberg et al. have demonstrated in their study that the main site of adiponectin clearance is the liver, and that kidneys only eliminate final degradation products (14). Despite the generally known protective effects of adiponectin, its role in CKD seems to be controversial. While several meta-analyses have linked higher adiponectin levels in CKD patients with lower risk of CVD mortality (15, 16), others have concluded that CVD mortality in CKD patients is associated with increased adiponectin levels (8).

Although numerous studies have indicated that increased circulating adiponectin is indisputably associated with CKD, the reasons for this rise still remain unclear. Since impairment of the adiponectin/receptor axis could contribute to the adiponectin rise, we sought to investigate if patients on hemodialysis (HD) have an altered expression of adiponectin receptors in PBMCs compared to healthy subjects.

\section{Materials and Methods}

\section{Subjects}

Thirty-one patients (19 males and 12 females; age range 27-76 years, age median 58 years) with CKD on hemodialysis were recruited from the Nephrology Clinic, Clinical Center of Serbia. The main causes of CKD in these patients were: chronic glomerulonephritis $(n=6)$, chronic renal insufficiency $(n=4)$, nephroangiosclerosis $(n=6)$, uric acid nephropathy $(n=2)$, Good-Pasture syndrome $(n=2)$, renal calculosis $(n=2)$, vesicoureteral reflux $(n=2)$, hypertension $(n=1)$, atrophia renis segmentalis $(n=1)$, lupus nephritis $(n=1)$, endemic nephropathy $(n=1)$, chronic pyelonephritis $(n=1)$, renal tuberculosis $(n=1)$, renal vasculitis $(n=1)$. The duration of hemodialysis ranged from 3 to 248 days, with an average of 90 days.

Thirty-three healthy subjects (15 males and 18 females; age range 27-60, age median 45) were selected for the control group. They were interviewed about their family history and health status. Inclusion criteria for the control group were absence of cardiovascular diseases in family history; absence of hypertension (diastolic blood pressure $<90 \mathrm{~mm} \mathrm{Hg}$ and/or systolic blood pressure < $140 \mathrm{~mm} \mathrm{Hg}$ ) and/or absence of any antihypertensive therapy; favorable lipid profile (according to Adult Treatment Panel III guidelines - ATP III); glucose $<6.1 \mathrm{mmol} / \mathrm{L}$; IMT in at least one carotid artery $<1 \mathrm{~mm}$.

The study was conducted according to the guidelines laid down in the Declaration of Helsinki. All the procedures involving human subjects were approved by the Ethical Committee of the Faculty of Pharmacy, University of Belgrade and School of Medicine, University of Belgrade. All the participants have signed an informed consent before the enrolment.

\section{Samples}

Blood samples were collected after a 12-hour fasting period into EDTA-containing tubes. Whole blood was centrifuged for $10 \mathrm{~min}$ at $3000 \mathrm{rpm}$; plasma was separated, frozen and stored at $-80{ }^{\circ} \mathrm{C}$ until analysis. PBMCs from whole blood were isolated using Ficoll-Paque ${ }^{\circledR}$ gradient and immediately added to TRIzol ${ }^{\mathrm{TM}}$ extraction (Invitrogen Life Technologies, Carlsbad, CA, USA) (TRI) reagent and then stored $-80{ }^{\circ} \mathrm{C}$ until RNA isolation. 


\section{Analytical methods}

Glucose, total cholesterol (TC), HDL-cholesterol (HDL-C), LDL-cholesterol (LDL-C), triglycerides (TG), urea, creatinine were measured by routine enzymatic methods in plasma using an ILab 300+ analyzer (Instrumentation Laboratory, Milan, Italy) and Randox Laboratories (Armdore, UK) reagents. Fasting insulin concentration was measured by the ECLIA method, on a COBAS ${ }^{\circ}$ INTEGRA 400 plus - Roche Diagnostics.

In the plasma of all subjects, circulating adiponectin was measured using a Human Total Adiponectin/Acrp30 Quantikine ELISA Kit. Sensitivity of this assay was $0.891 \mathrm{ng} / \mathrm{mL}$, intra-assay and inter-assay coefficients of variation were $3.4 \%$ and $5.8 \%$ respectively. All the samples were measured in duplicates.

Methods used for RNA isolation, reverse transcription and real-time PCR were described in detail elsewhere (17). Briefly, RNA was isolated using a TRIzol $^{\mathrm{TM}}$ extraction (Invitrogen Life Technologies, Carlsbad, CA, USA) (TRI) reagent according to manufacturer's protocol and quantified by absorbance spectrometry at $260 \mathrm{~nm}$. In order to estimate organic and protein contamination, in every sample absorbance was measured at $230 \mathrm{~nm}$ and $280 \mathrm{~nm}$, respectively. RNA integrity was evaluated by electrophoresis on 1\% agarose gel. Reverse transcription and real-time PCR experiments were performed on the 7500 Real-Time PCR System (Applied Biosystems, Foster City, CA, USA) using TaqMan ${ }^{\circledR}$ reagent-based chemistry. Data were expressed as a ratio between the target gene mRNA level and the mRNA level of the housekeeping gene (beta-actin).

\section{Statistical analysis}

Statistical analysis was performed using IBM ${ }^{\circledR}$ SPSS ${ }^{\circledR}$ Statistics version 22 software. Distribution of data was tested with the Shapiro-Wilk test. Normally distributed data are presented as mean \pm standard deviation. For the non-normally distributed data logarithmic transformation was performed and these data are presented as geometrical means and 95\% confidence intervals. If data could not be transformed to fit normal distribution they are presented as medians and interquartile ranges. Statistical tests used for normally distributed data were: Pearson's correlation, independent samples t-test and ANOVA. Adjustments were performed by using the analysis of covariance (ANCOVA). For the data that had not been normally distributed, Mann-Whitney $U$ test and Spearman's correlation were used. Chi-square test was used for the comparison of categorical variables. Statistically significant $\mathrm{p}$-value was less than 0.05 .

\section{Results}

Anthropometric and biochemical data of healthy subjects and patients on HD are presented in Table $I$. Levels of urea, creatinine, TG, HDL-C and hsCRP as well as IMT were increased in HD patients compared to healthy subjects $(P<0.001, P<0.001, P=0.006$, $P<0.001, P<0.001, P<0.001$, respectively). Levels of insulin were also significantly higher in patients compared to control subjects $(P<0.001)$. On the contrary, $\mathrm{BMI}$ and $\mathrm{TC}$ were significantly higher in the control group $(P=0.001, P=0.047$, respectively), while LDL-C levels showed no difference between the groups $(P=0.084)$.

Table I Basic anthropometric, lipid status, inflammation parameters in healthy children according to the age subgroups.

\begin{tabular}{|l|c|c|c|}
\hline & CG & HD & P \\
\hline Male/female & $15 / 18$ & $19 / 12$ & $0.132^{* * *}$ \\
\hline Age (years) & $45 \pm 9$ & $55 \pm 15$ & $0.003^{*}$ \\
\hline BMI $\left(\mathrm{kg} / \mathrm{m}^{2}\right)$ & $24.9 \pm 3.6$ & $22.2 \pm 3.0$ & $0.002^{*}$ \\
\hline Urea $(\mathrm{mmol} / \mathrm{L})$ & $5.76(5.33-6.23)$ & $21.16(19.60-22.84)$ & $<0.001^{*}$ \\
\hline Creatinine $(\mu \mathrm{mol} / \mathrm{L})$ & $86.5(82.7-90.4)$ & $982.4(929.4-1038.4)$ & $<0.001^{*}$ \\
\hline $\mathrm{TC}(\mathrm{mmol} / \mathrm{L})$ & $5.07 \pm 0.92$ & $4.60 \pm 0.94$ & $0.047^{*}$ \\
\hline $\mathrm{HDL}-\mathrm{C}(\mathrm{mmol} / \mathrm{L})$ & $1.60(1.47-1.75)$ & $0.85(0.76-0.95)$ & $<0.001^{*}$ \\
\hline $\mathrm{LDL}-\mathrm{C}(\mathrm{mmol} / \mathrm{L})$ & $3.09 \pm 0.76$ & $2.73 \pm 0.83$ & $0.084^{*}$ \\
\hline $\mathrm{TG}(\mathrm{mmol} / \mathrm{L})$ & $1.24(1.06-1.47)$ & $1.75(1.46-2.11)$ & $0.006^{*}$ \\
\hline $\mathrm{hsCRP}(\mathrm{mg} / \mathrm{L})$ & $1.16(0.71-1.45)$ & $5.20(2.62-11.17)$ & $<0.001^{* *}$ \\
\hline Insulin $(\mu \mathrm{U} / \mathrm{L})$ & $8.90 \pm 3.48$ & $42.29 \pm 39.91$ & $<0.001^{*}$ \\
\hline Adiponectin $(\mu \mathrm{gg} / \mathrm{mL})$ & $9.60(7.64-12.04)$ & $13.42(10.72-16.80)$ & $0.036^{*}$ \\
\hline IMT $(\mathrm{mm})$ & $0.45(0.00-0.50)$ & $0.65(0.55-0.70)$ & $<0.001^{* *}$ \\
\hline
\end{tabular}

Urea, Creatinine, HDL-C, TG, adiponectin and IMT are logarithmically transformed before statistical analysis and presented as geometrical mean and $95 \%$ confidence intervals $(\mathrm{Cl})$. Age, BMI, TC and LDL-C are presented as mean \pm standard deviation.

*Variables were compared by Student's t-test.

**Variables were compared by Mann-Whitney U test.

$* * *$ Variables were compared by Chi-square test. 


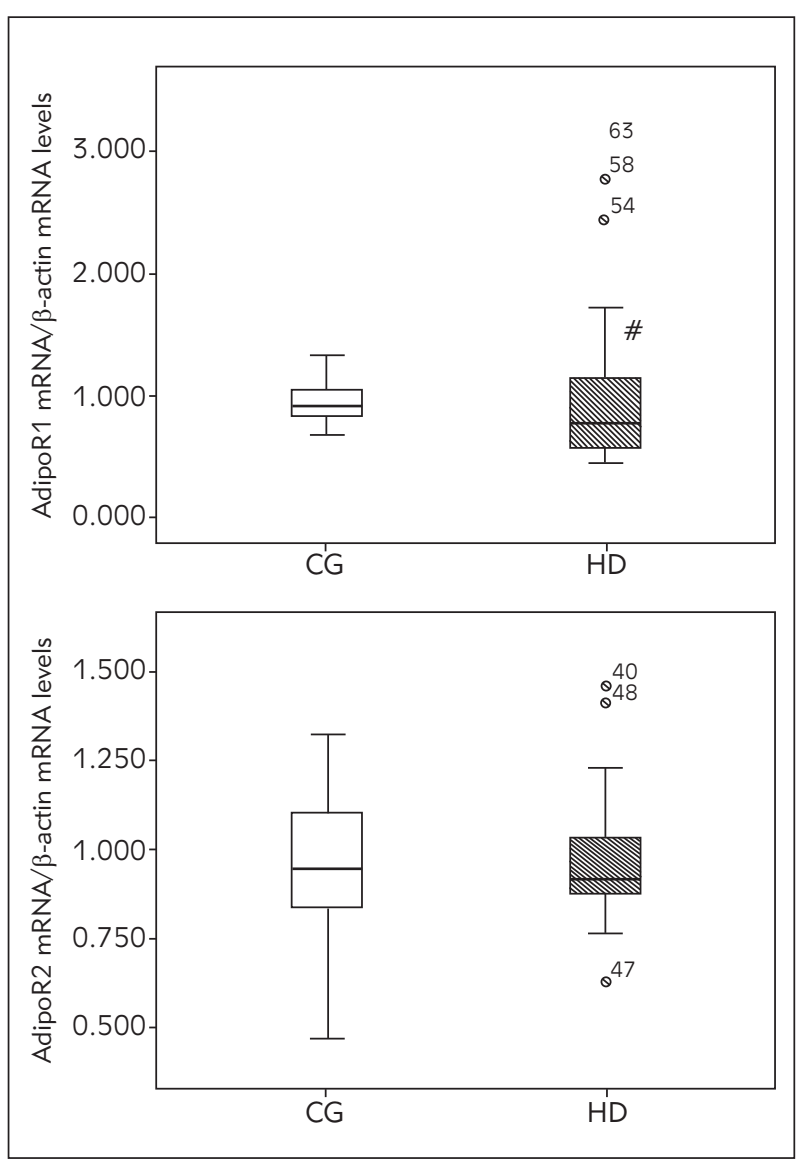

Figure 1 Normalized AdipoR1 (A) and Adipor2 (B) mRNA levels from PBMCs of healthy subjects (CG) and CKD patients on hemodialysis (HD).

\# - significantly different compared to healthy subjects; $\mathrm{P}=0.034$.
Plasma adiponectin levels were significantly higher in patients compared to control group $(\mathrm{P}=0.036$, Table I). After adjustment for age, BMI and creatinine, this difference became even more significant $(P=0.004)$. Males had significantly lower adiponectin levels than females in the control group (6.26 (4.76-8.22) $\mu \mathrm{g} / \mathrm{mL}$ vs. 13.70 (10.55-17.80) $\mu \mathrm{g} / \mathrm{mL}, \mathrm{p}<0.001)$ as well as in the patient group (10.54 (8.17-13.60) $\mu \mathrm{g} / \mathrm{mL}$ vs. 19.84 (14.7926.63) $\mu \mathrm{g} / \mathrm{mL}, \mathrm{P}=0.004)$. After adjustment for $\mathrm{BMI}$ these differences remained significant $(P=0.009$, $\mathrm{P}=0.003$, respectively).

Furthermore, significantly lower expression of PBMCs AdipoR1 mRNA was found in patients compared to healthy subjects $(P=0.034)$, while AdipoR2 mRNA levels were similarly expressed in PBMCs in both groups (Figure 1). We have found a strong correlation between adiponectin receptors in CG ( $r=$ $0.666, P<0.001)$. However, correlation between the two adiponectin receptors was not demonstrated in the patient group $(r=-0.061, P=0.757)$. We have also demonstrated a significant negative correlation between AdipoR1 mRNA levels and insulin concentration, but only in the patient group $(r=-0.469$, $\mathrm{P}=0.021)$.

Correlations of adiponectin with other parameters, in healthy subjects and patients with CKD, are presented in Table II. In both groups, adiponectin negatively correlated with creatinine, insulin, TG, and positively with HDL-C. Negative correlation was observed between adiponectin and BMI only in the control group.

Table II Correlation of adiponectin and different parameters in healthy subjects (CG) and CKD patients on hemodialysis (HD).

\begin{tabular}{|c|c|c|c|c|}
\hline \multicolumn{5}{|c|}{ Adiponectin $(\mu \mathrm{g} / \mathrm{mL})$} \\
\hline & \multicolumn{2}{|c|}{ CG } & \multicolumn{2}{|c|}{$\mathrm{HD}$} \\
\hline & $r$ & $P$ & $r$ & $P$ \\
\hline Age (years) & 0.059 & 0.743 & 0.123 & 0.509 \\
\hline BMI $\left(\mathrm{kg} / \mathrm{m}^{2}\right)$ & -0.613 & $<0.001$ & -0.193 & 0.317 \\
\hline Urea $(\mathrm{mmol} / \mathrm{L})$ & 0.028 & 0.879 & 0.222 & 0.229 \\
\hline Creatinine $(\mu \mathrm{mol} / \mathrm{L})$ & -0.472 & 0.006 & -0.375 & 0.038 \\
\hline $\mathrm{TC}(\mathrm{mmol} / \mathrm{L})$ & 0.120 & 0.505 & 0.070 & 0.707 \\
\hline $\mathrm{HDL}-\mathrm{C}(\mathrm{mmol} / \mathrm{L})$ & 0.672 & $<0.001$ & 0.584 & 0.001 \\
\hline LDL-C (mmol/L) & 0.192 & 0.293 & 0.157 & 0.415 \\
\hline $\mathrm{TG}(\mathrm{mmol} / \mathrm{L})$ & -0.490 & 0.004 & -0.488 & 0.005 \\
\hline $\mathrm{hsCRP}(\mathrm{mg} / \mathrm{L})$ & -0.305 & 0.084 & -0.356 & 0.074 \\
\hline Insulin $(\mu \mathrm{U} / \mathrm{L})$ & -0.386 & 0.038 & -0.506 & 0.012 \\
\hline IMT (mm) & 0.162 & 0.483 & 0.105 & 0.561 \\
\hline AdipoR1* & -0.041 & 0.822 & 0.131 & 0.481 \\
\hline AdipoR2* & -0.131 & 0.468 & -0.177 & 0.368 \\
\hline
\end{tabular}

* parameters were tested by Spearman's correlation analysis. 


\section{Discussion}

In this study, we have shown that downregulation of AdipoR1 mRNA in PBMCs (Figure 1) and increase in circulating adiponectin levels are present in CKD patients on hemodialysis (Table I). Patients were significantly older than controls, but since age did not significantly correlate with either adiponectin or adiponectin receptors, we feel that the obtained results were not influenced by the age difference between the observed subjects.

Increased adiponectin levels in patients on hemodialysis were demonstrated in numerous studies over the past decade, but the reason(s) for this rise have remained unclear. Although kidneys play an important role in the elimination of adiponectin, its elevated levels cannot solely be linked to the deterioration of their function (18). It has been shown that urinary adiponectin levels are also increased in patients with CKD and that after successful kidney transplantation adiponectin levels do decrease, but still remain higher compared to healthy individuals (13). Overproduction and secretion of adiponectin by adipose tissue could be an important contributor to its increase in circulation, but data regarding this subject are not consistent and require further clarifications. While Martinez et al. reported increased expression of both adiponectin mRNA and protein in visceral and subcutaneous fat tissue in patients with end stage kidney disease (19), Marchlewska et al. (20) demonstrated opposite results.

Another mechanism that could contribute to the increase of adiponectin levels in HD patients is the loss of its effects due to downregulation of its receptors (21), which has already been demonstrated in patients with chronic heart failure (CHF) (22) and coronary artery disease (23). In our study, we have found that patients on hemodialysis have decreased expression of AdipoR1 mRNA in PBMCs compared to healthy subjects (Figure 1). This implies that various pathological processes in chronic kidney disease cause downregulation of AdipoR1. Long term decrease of AdipoR1 mRNA levels could ultimately lead to decrease of AdipoR1 protein levels on cell surface creating a possibility for the development of »adiponectin resistance«.

Initial stimuli for this downregulation are still unclear. Previous studies have suggested that increased insulin levels are associated with CKD, which was confirmed by our study. We have also found a significant negative correlation between AdipoR1 mRNA levels and insulin concentration but only in patients which suggests that the observed AdipoR1 downregulation could be partly attributed to insulin. Previous studies have also underlined the influence of insulin on AdipoR1 expression. Namely, it has been shown that insulin leads to downregulation of AdipoR1 expression, through the activation of phosphoinositide 3-kinase (PI3-kinase)/Foxo1 pathway (21). Moreover, a strong correlation between the two adiponectin receptors was demonstrated only in CG, while in patients on HD this connection was lost. Hence, the downregulation of AdipoR1 could be a consequence of the pathological processes that act solely upon the regulation of the expression of AdipoR1, but not AdipoR2.

Our results are not in line with two previous studies in which CKD patients had elevated expression of adiponectin receptors $(19,24)$. These discrepancies could be a consequence of several factors. Patients in previous studies had higher BMI $\left(26.0 \pm 5.0\right.$ and $\left.27.3 \pm 4.4 \mathrm{~kg} / \mathrm{m}^{2}\right)$ than patients in our study $\left(22.2 \pm 3.0 \mathrm{~kg} / \mathrm{m}^{2}\right)$. In line with this, Tsigalou et al. showed that beneficial effects of high adiponectin levels on survival were observed only in a subgroup of HD patients with high BMI $\left(>24 \mathrm{~kg} / \mathrm{m}^{2}\right)$ which could be due to the upregulation of adiponectin receptors in CKD patients with higher BMI (25). Also, subjects in previous studies had been on hemodialysis for a much longer period of time (average: 3.5 years) than our patients (average: 90 days). And finally, in the study by Martinez et al. (19) patients that had kidney transplantation as well as patients with diabetes mellitus type two were included, while in our study those subjects were excluded.

We have also shown that adiponectin is related to lipid parameters in both groups, negatively with TG and positively with HDL-C (Table II). Two previous studies have shown that despite the fact that adiponectin was positively associated with HDL-C, high rather than low adiponectin was related to increased all-cause mortality in CKD patients (17) and increased all-cause mortality and progression to end stage renal disease (ESKD) in type I diabetic patients (26). Namely, patients with end stage kidney disease often have altered $\mathrm{HDL}$ particles composition, leading to impaired functions of HDL and loss of its antiatherogenic properties $(27,28)$ which is associated with increased CVD risk (29).

It should be noted that the results presented in this study have certain limitations. Firstly, generalization of our conclusion is limited by the small sample size and low statistical power, so a case-control study including more subjects is needed to further elucidate the relation between adiponectin and the development of CKD. Secondly, various causes led to kidney failure in these patients which could have also influenced our results. Thirdly, we have only measured mRNA levels of adiponectin receptors, but not their protein levels which could have strengthened our findings of the receptors downregulation.

In summary, our study has demonstrated downregulation of AdipoR1 and higher levels of circulating adiponectin in CKD patients on hemodialysis. It seems that, in such a complex milieu as one created 
during CKD, AdipoR1 is downregulated, which in the long term could reduce AdipoR1 protein levels thus leading to a state of "adiponectin resistance».

Acknowledgment. This study was financially supported by a grant from the Ministry of Education, Science and Technological Development, Serbia (Project numbers 175035).

\section{References}

1. Ye R, Scherer PE. Adiponectin, driver or passenger on the road to insulin sensitivity? Mol Metab 2013; 2: 133-41.

2. Yamauchi T, Kadowaki T. Adiponectin receptor as a key player in healthy longevity and obesity-related diseases. Cell Metab 2013; 17: 185-96.

3. Holland WL, Miller RA, Wang ZV, Sun K, Barth BM, Bui $\mathrm{HH}$, et al. Receptor-mediated activation of ceramidase activity initiates the pleiotropic actions of adiponectin. Nat Med 2011; 17: 55-63.

4. Wolf AM, Wolf $D$, Rumpold H, Enrich B, Tilg H. Adiponectin induces the anti-inflammatory cytokines IL-10 and IL-1RA in human leukocytes. Biochem Biophys Res Commun 2004; 323: 630-5.

5. Lovren F, Pan Y, Quan A, Szmitko PE, Singh KK, Shukla PC, et al. Adiponectin primes human monocytes into alternative anti-inflammatory M2 macrophages. Am J Physiol Heart Circ Physiol 2010; 299: 656-63.

6. Rutkowski JM, Wang ZV, Park AS, Zhang J, Zhang D, Hu $M C$, et al. Adiponectin promotes functional recovery after podocyte ablation. J Am Soc Nephrol 2013; 24: 268-82.

7. Tulubus F, Mete R, Oznur M, Topcu B. The role of adipocytokines in colon cancer and adenomas. J Med Biochem 2014; 33; 135-42.

8. El-Shafey EM, Shalan M. Plasma adiponectin levels for prediction of cardiovascular risk among hemodialysis patients. Ther Apher Dial 2014; 18: 185-92.

9. Zoccali C. Cardiovascular risk in uraemic patients: is it fully explained by classical risk factors? Nephrol Dial Transplant 2000; 15: 454-7.

10. Zoccali C, Mallamaci F, Panuccio V, Tripepi G, Cutrupi S, Parlongo $S$, et al. Adiponectin is markedly increased in patients with nephrotic syndrome and is related to metabolic risk factors. Kidney Int Suppl 2003; 84: 98-102.

11. Cvetković T, Veličković-Radovanović $R$, Stojanović $D$, Stefanović N, Ignjatović A, Stojanović I, Sladojević N, Pavlović D. Oxidative and nitrosative stress in stable renal transplant recipients with respect to the immunosuppression protocol - differences or similarities? J Med Biochem 2015; 34: 295-303.

12. Isobe T, Saitoh S, Takagi S, Takeuchi H, Chiba Y, Katoh $\mathrm{N}$, et al. Influence of gender, age and renal function on plasma adiponectin level: the Tanno and Sobetsu study. Eur J Endocrinol 2005; 153: 91-8.

\section{Conflict of interest statement}

The authors stated that they have no conflicts of interest regarding the publication of this article.

13. Chudek J, Adamczak M, Karkoszka H, Budziński G, Ignacy W, Funahashi T, et al. Plasma adiponectin concentration before and after successful kidney transplantation. Transplant Proc 2003; 35: 2186-9.

14. Halberg N, Schraw TD, Wang ZW, Kim JY, Yi J, Hamilton $M P$, et al. Systematic fate of the adipocyte-derived factor adiponectin. Diabetes 2009; 58: 1961-70.

15. Iwashima Y, Horio T, Kumada M, Suzuki Y, Kihara S, Rakugi $\mathrm{H}$, et al. Adiponectin and renal function, and implication as a risk of cardiovascular disease. Am J Cardiol 2006; 98: 1603-8.

16. Zoccali C, Mallamaci F, Tripepi G, Benedetto FA, Cutrupi $\mathrm{S}$, Parlongo $\mathrm{S}$, et al. Adiponectin, metabolic risk factors, and cardiovascular events among patients with endstage renal disease. J Am Soc Nephrol 2002; 13: 134-41.

17. Novaković I, Maksimović N, Pavlović A, Žarković M, Rovčanin B, Mirković D, Pekmezović T, Cvetković D. Introduction to molecular genetic diagnostics. J Med Biochem 2014; 33: 3-7.

18. Jia T, Carrero JJ, Lindholm B, Stenvinkel P. The complex role of adiponectin in chronic kidney disease. Biochimie 2012; 94: 2150-6.

19. Martinez-Cantarin PM, Waldman S, Doria C, Frank AM, Maley WR, Ramirez CB, et al. The adipose tissue production of adiponectin is increased in end stage renal disease. Kidney Int 2013; 83: 487-94.

20. Marchlewska A, Stenvinkel P, Lindholm B, Danielsson A, Pecoits-Filho R, Lönnqvist $F$, et al. Reduced gene expression of adiponectin in fat tissue from patients with endstage renal disease. Kidney Int 2004; 66: 46-50.

21. Cui XB, Wang C, Li L, Fan D, Zhou Y, Wu D, et al. Insulin decreases myocardial adiponectin receptor 1 expression via PI3K/Akt and FoxO1 pathway. Cardiovasc Res 2012; 93: 69-78.

22. Springer J, Anker SD, Doehner W. Adiponectin Resistance in Heart Failure and the Emerging Pattern of Metabolic Failure in Chronic Heart Failure. Circ Heart Fail 2010; 3: 181-2.

23. Sopić M, Joksić J, Spasojević-Kalimanovska V, Kalimanovska-Oštrić D, Anđelković K, Jelić-lvanović Z. Are decreased AdipoR1 mRNA levels associated with adiponectin resistance in coronary artery disease patients? Clin Exp Pharmacol Physiol 2015; doi: 10.1111/14401681.12361. 
24. Shen YY, Charlesworth JA, Kelly JJ, Loi KW, Peake PW. Up-regulation of adiponectin, its isoforms and receptors in end-stage kidney disease. Nephrol Dial Transplant 2007; 22: 171-8.

25. Tsigalou C, Chalikias G, Kantartzi K, Tziakas D, Kampouromiti D, Vargemezis V, et al. Differential Effect of Baseline Adiponectin on All-Cause Mortality in Hemodialysis Patients Depending on Initial Body Mass Index. LongTerm Follow-Up Data of 4.5 Years. Journal of Renal Nutrition 2012; 23: 45-56.

26. Jorsal A, Tarnow T, Frystyk J, Lajer M, Flyvbjerg A, Parving $\mathrm{HH}$, et al. Serum adiponectin predicts all-cause mortality and end stage renal disease in patients with type I diabetes and diabetic nephropathy. Kidney Int 2008; 74: 649-54.
27. Stenvinkel P. Adiponectin in chronic kidney disease: a complex and context sensitive clinical situation. J Ren Nutr 2011; 21: 82-6.

28. Vekic J, Zeljkovic A, Bogavac-Stanojevic N, Jelic-Ivanovic Z, Spasojevic-Kalimanovska V, Simic-Ogrizovic S, et al. Cox proportional hazard model analysis of survival in end-stage renal disease patients with small-sized highdensity lipoprotein particles. Clinical Biochemistry 2011; 44: 635-41.

29. Zeljkovic A, Vekic J, Spasojevic-Kalimanovska V, JelicIvanovic Z, Bogavac-Stanojevic N, Gulan B, et al. LDL and HDL subclasses in acute ischemic stroke: prediction of risk and short-term mortality. Atherosclerosis 2010; 210: 548-55.

Received: November 30, 2015

Accepted: January 19, 2016 